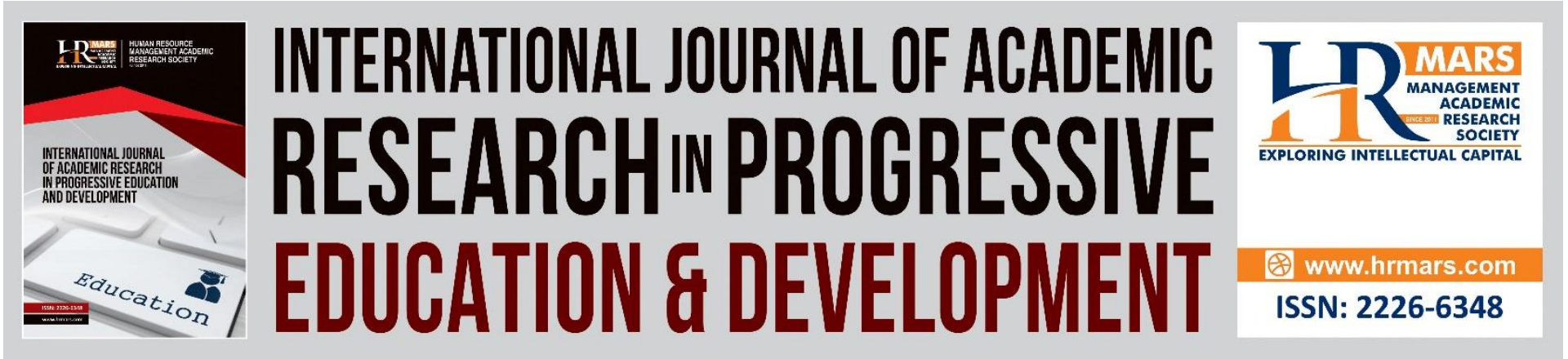

\title{
A Review of Psychosocial Learning Environment
}

Nor Sa'adah Jamaluddin, Suhaida Abd. Kadir, Siti Noormi Alias \& Arnida Abdullah

To Link this Article: http://dx.doi.org/10.6007/IJARPED/v10-i3/11189

DOI:10.6007/IJARPED/v10-i3/11189

Received: 04 July 2021, Revised: 08 August 2021, Accepted: 29 August 2021

Published Online: 28 September 2021

In-Text Citation: (Jamaluddin et al., 2021)

To Cite this Article: Jamaluddin, N. S., Kadir, S. A., Alias, S. N., \& Abdullah, A. (2021). A Review of Psychosocial Learning Environment. International Journal of Academic Research in Progressive Education and Development, 10(3), 804-808.

\section{Copyright: (C) 2021 The Author(s)}

Published by Human Resource Management Academic Research Society (www.hrmars.com)

This article is published under the Creative Commons Attribution (CC BY 4.0) license. Anyone may reproduce, distribute, translate and create derivative works of this article (for both commercial and non-commercial purposes), subject to full attribution to the original publication and authors. The full terms of this license may be seen

at: http://creativecommons.org/licences/by/4.0/legalcode

\section{Vol. 10(3) 2021, Pg. $804-808$}

\section{http://hrmars.com/index.php/pages/detail/IJARPED}

JOURNAL HOMEPAGE

Full Terms \& Conditions of access and use can be found at http://hrmars.com/index.php/pages/detail/publication-ethics 


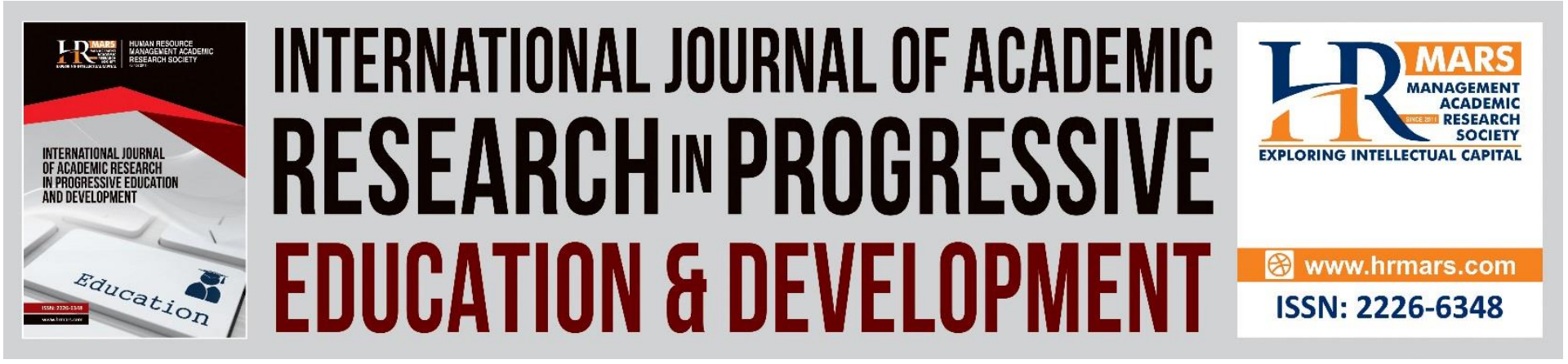

\title{
A Review of Psychosocial Learning Environment
}

\author{
Nor Sa'adah Jamaluddin', Suhaida Abd. Kadir², Siti Noormi \\ Alias $^{3}$ \& Arnida Abdullah 4 \\ ${ }^{1}$ Department of Accounting and Finance, Faculty of Management and Economics, Universiti \\ Pendidikan Sultan Idris, 35900 Tanjung Malim, Perak, Malaysia, ${ }^{2-4}$ Faculty of Educational \\ Studies, Universiti Putra Malaysia, Serdang
}

\begin{abstract}
The education field is one of the aspects that have been linked to the economic field. Based on the Malaysian Education Blueprint 2013-2025, the learning environment is one of the aspects that should be improved in order to achieve the best academic performance. The aim of this study is to review a learning environment that influences achievement in the education field. This paper explores the meaning of the psychosocial learning environment by various researchers and even explores one of the most popular dimensions of the psychosocial learning environment, such as teacher and student relationships that is believed to be capable of affecting the academic performance. A good relationship between the teacher and student can leave positive impacts on the student's level of motivation and attitude towards their learning. The findings of previous researchers were also included to support the arguments used in this study.
\end{abstract}

Keywords: Psychosocial Learning Environment, Learning Environment, Psychology, Social Aspects, Academic Performance

\section{Introduction}

The learning environment refers to all aspects of the environment that have the space and opportunity to promote learning (Joyce \& Weil, 1996) be it from social, psychological and pedagogical aspects (Fraser, 1998). This learning environment is also defined as the atmosphere or environment around which learning takes place that directly affects the success of learning (Tessmer \& Harris, 1992). Che Ahmad et al., (2013) meanwhile explained that the learning environment is a physical space in which learning takes place, and is referred to as the space allocated for learning be it classrooms, science laboratories, workshops, fields or even offices.

Ramsden (1991) explained that the learning environment is closely related to the experiences of the students in the context of their teaching. This is because the learning environment is a place where students and educators gather for a certain period of time for the purpose of participating in learning activities (Biggs, 1999). Hence, the environments created throughout the learning activities are considered as an important component in the teaching and learning process (Puteh et al., 2014).

The learning environment response that serves as an important component in the teaching and learning process (Puteh et al., 2014) is a sequence of the influences received 
from the environment towards the learning outcomes of the students, be it from the perspective of skills or cognitive constructs or even student behavior (Che Ahmad et al., 2013; Fraser, 1998). This is in line with explanations by Saad (1997) which considers that the learning environment measures the surroundings that directly affect the success of one's learning, but the effectiveness of this learning environment is determined by other environmental factors surrounding it such as the environment and supportive atmosphere.

\section{Psychosocial Learning Environment}

The combination of psychological and social aspects is a common definition of a psychosocial environment that is the link between the psychological development of a student and its interaction with the social environment (Che Ahmad et al., 2013). Psychosocial terms are often used to describe the unique processes that occur in a person as a result of their interactions with the environment. Fraser (1994) explains the psychosocial environment involves the relationship between teachers and students such as the collaborations and interactions between teachers and students, between students as well as students and their environments.

\section{A Dimension of Psychosocial Learning Environments}

The dimensions of teacher and student relationships is often the main focus of the previous study of the sequences of the effects and influences gained by the relationship that existed on the student's academic achievement. Teachers' relationship with students and student achievement shows a positive and significant relationship and thus proves that teachers act as a driving force for student success (Chen et al., 2017; Mokhtar, 2012). The good relationship between the teacher and the student is based on the communication between teachers and students that encourages teachers to help students deal with problems in the learning process (Ballantine, 1997; Colvin, \& Schloscer, 1998;

Gorham, \& Christopel, 1990; Ginott, 1972; Ishak, \& Mohammad, 2001; Nor, 2005; Okula, 1999; Rudduck, 1996; Wiseman, \& Bogner, 2003).

In the context of schools, a teacher who is effective, well-liked and honoured by the students (Hassan \& Mohd, 1999) should have good and unique communication skills. This is because communication is a process inherent in the sharing of experiences by teachers with students and students with teachers in contributing towards the forming of relationships between humans. A study on secondary school students discovered that the importance of the relationship between teachers and students exceeds the importance of the approach used by teachers in delivering their teaching. This is because the level of student interaction with educators contributes to the success of an academic student as well as the motivation and success of the students through their role as motivators for students through the teaching and learning process (Ballantine, 1997; Colvin, \& Schloscer, 1998; Ishak, \& Mohammad, 2001; Okula, 1999).

Rahim, Mat Rashid and Hamzah (2015) through a study of 195 final year students of UPM and UTM on the relationship between students' participation in learning with their reflective level of thinking found that the refusal of students to actively participate in learning was due to the lack of support provided by teachers towards positive developments highlighted by students. Refusal to engage actively in learning results in the cognitive development of students left stunted and the transformation of the minds of the students unable to be fulfilled effectively and brilliantly. 
DEVELOPMENT

Vol. 10, No. 3, 2021, E-ISSN: 2226-6348 @ 2021 HRMARS

Empirical studies have documented the positive effects of attentive or caring behaviour and teacher relationships with assisting students on academic achievement (Ishak, \& Mohammad, 2001; see also Okula, 1999; Colvin, \& Schloscer, 1998; Ballantine, 1997). This proves that caring attitudes of teachers towards students is observed to leave a positive relationship towards academic efforts and social responsibility as well as prosocial goals. Teachers who are concerned or care about the students are seen by the students as teachers who are democratic when interacting, take into account individual differences in learning, serve as role models for students in their learning and provide constructive feedback.

\section{Conclusion}

Teacher and student relationships in teaching and learning sessions are a major contributor to the success of students in their academic achievement. This is because, through the good relationships that exist, the increased motivation and attitude of students towards learning will continue to increase from time to time. Communication skills are an important skill in ensuring the relationship between teachers and students remains in good condition, aside from creating a positive learning environment. Hence, teachers and students need to work together to build this relationship through improved communication skills, and be prepared to help one another to ensure that teaching and learning sessions achieve the goals and objectives that have been set.

\section{Corresponding Author}

Nor Sa'adah binti Jamaluddin

Email: norsaadah@fpe.upsi.edu.my

\section{References}

Ballantine, J. H. (1997). The sociology of education; A systemic analysis. Edisi ke-4. New Jersey: Pearson Education Inc.

Che Ahmad, C. N., Osman, K., \& Halim, L. (2013). Persekitaran pembelajaran aspek fizikal dan psikososial. Bangi: Universiti Kebangsaan Malaysia.

Chen, C., Fan, J., \& Jury, M. (2017). Are perceived learning environments related to subjective well-being ? A visit to university students. Learning and Individual Differences, 54, 226233. https://doi.org/10.1016/j.lindif.2017.01.001.

Colvin, C., \& Schloscer, L. K. (1998). Developing academic confidence to build literacy: What teachers can do. Journal of Adolescent and Adult Literacy, 41(4): 272-281.

Fraser, B. J. (1994). Classroom and School Climate. In. Gabel, D. (Ed.). Handbook of Research on Science Teaching and Learning, 493-541. New York: Mac-Millan.

Fraser, B. J. (1998). Classroom Environment Instruments: Development, Validity and Applications. Learning Environments Research, 1, 7-33.

Ginott, H. (1972). Teacher and child. New York: Avon Books.

Gorham, J., \& Christopel, D. M. (1990). The relationship of teacher's use of humour in the classroom to Immediacy and Student Learning. Communication Education, 39: 46-61.

Hassan, A., \& Mohd, A. (1999). Komunikasi untuk guru. Utusan Publications \& Distributors Sdn. Bhd.

Biggs, J. (1999). What the Student Does: teaching for enhanced learning. Higher Education Research \& Development, 18:1, 57-75.

Joyce, B., \& Weil, M. (1996). Models of teaching ( $5^{\text {th }}$ ed.). Englewood Cliffs, NJ: Prentice-Hall. 
Ishak, M. N., \& Mohammad, N. S. (2001). Gaya pertautan dan komitmen terhadap profesion perguruan di kalangan guru-guru pelatih. Kertas Kerja International Conference on Challenges and prospects in teacher education. Shah Alam: Concorde Hotel.

Nor, M. R. (2005). Perkaitan di antara budaya sekolah dengan pencapaian akademik pelajar di Negeri Sembilan [Tesis Doktor Falsafah, Universiti Kebangsaan Malaysia].

Saad, M. B. (1997). Korelasi antara persekitaran pembelajaran dengan pendekatan pembelajaran dengan pencapaian Ekonomi STPM [Tesis Sarjana Pendidikan, Universiti Kebangsaan Malaysia].

Mokhtar, S. B. (2012). Faktor persekitaran pembelajaran, pendekatan pembelajaran dan kemahiran generik dalam kalangan pelajar politeknik [Tesis Doktor Falsafah, Universiti Kebangsaan Malaysia]

Okula, S. (1999). Creating a positive school culture: Strategies that work. Business Education Forum, 54 (2), 7-13.

Puteh, M., Adnan, M., Ibrahim, M. H., Noh, M. N., \& Che Ahmad, C. N. (2014). An analysis of comfortable teaching and learning environment: community response to climate change in school. Procedia-Social and Behavioral Sciences, 116, 285-290. https://doi.org/10.1016/j.sbspro.2014.01.209

Rahim, N. H. Z, Rashid, M. A., \& Hamzah, R. (2015). Hubungan antara penglibatan dalam teknikal dan vokasional. Journal of Human Capital Development, 8(1), 105-120.

Ramsden, P. (1991). A Performance Indicator of Teaching Quality in Higher Education: The Course Experience.

Rudduck, J., Chaplain, R., \& Wallace, G. (1996). Reviewing the conditions of learning in school. In: Rudduck, J., Chaplain, R., \& Wallace, G., Eds., School Improvement: What Students Can Tell Us? London: David Fulton Publishers, 170-176.

Tessmer, M., \& Harris, D. (1992). Analyzing the instructional setting: Environmental analysis. London/Bristol, PA: Kogan Page/Taylor and Francis.

Wiseman, M., \& Bogner, F. X. (2003). A higher-order model of ecological values and its relationship to personality. Personality and Individual Differences, 34, 783-794. 